\title{
Milk Urea Concentration in Dairy Sheep: Accounting for Dietary Energy Concentration
}

\author{
Valeria Giovanetti ${ }^{1}$, Filippo Boe ${ }^{2}$, Mauro Decandia ${ }^{1}$, Giovanni Cristoforo Bomboi ${ }^{3}$, \\ Alberto Stanislao Atzori ${ }^{2}$ (D), Antonello Cannas ${ }^{2, *(D)}$ and Giovanni Molle ${ }^{1}$ \\ 1 Servizio Ricerca per la Zootecnia, AGRIS Sardegna, 07040 Olmedo, Italy; vgiovanetti@agrisricerca.it (V.G.); \\ mdecandia@agrisricerca.it (M.D.); gmolle@agrisricerca.it (G.M.) \\ 2 Dipartimento di Agraria, Sezione di Scienze Zootecniche, Università di Sassari, Viale Italia 39, 07100 Sassari, \\ Italy; filippoboe@gmail.com (F.B.); asatzori@uniss.it (A.S.A.) \\ 3 Dipartimento di Medicina Veterinaria, Università di Sassari, Via Vienna 2, 07100 Sassari, Italy; \\ gcbomboi@uniss.it \\ * Correspondence: cannas@uniss.it
}

Received: 13 November 2019; Accepted: 6 December 2019; Published: 11 December 2019

Simple Summary: In this paper, we show that milk urea concentration (MUC) of dairy ewes is markedly affected not only by dietary protein concentration, as evidenced by previous research, but also by dietary energy concentration. Thus, to avoid misleading interpretations, the utilization of MUC as indicator of the protein status of ewes should account for the dietary energy concentration. Minimal, optimal, and maximal MUC values for different combinations of dietary energy and protein are proposed. Because frequent bulk tank MUC analysis is easy to perform and cost-effective, the reference values proposed here can be used for optimizing sheep milk and reproductive performances while curbing $\mathrm{N}$ release from excreta.

\begin{abstract}
In dairy sheep milk urea concentration (MUC) is highly and positively correlated with dietary crude protein $(\mathrm{CP})$ content and, to a lesser extent, with protein intake. However, the effect of dietary energy and carbohydrate sources on MUC of lactating ewes is not clear. Thus, the objective of this study was to assess the effects of diets differing in energy concentration and carbohydrate sources on MUC values in lactating dairy ewes. Two experiments were conducted (experiment 1 , E1, and experiment 2, E2) on Sarda ewes in mid and late lactation kept in metabolic cages for 23 d. In both experiments, homogeneous groups of five ewes were submitted to four (in E1) or three (in E2) dietary treatments, consisting of pelleted diets ranging from low energy (high-fiber diets: 1.2-1.4 Mcal of net energy for lactation $\left(\mathrm{NE}_{\mathrm{L}}\right)$ ) to high energy (high-starch diets: 1.7-1.9 Mcal of $\mathrm{NE}_{\mathrm{L}}$ ) contents, but with a similar CP concentration (18.4\% dry matter (DM), on average). Each diet had a different main ingredient as follows: corn flakes, barley meal, beet pulp, or corn cobs in E1 and corn meal, dehydrated alfalfa, or soybean hulls in E2. Regression analysis using treatment means from both experiments showed that the best predictor of $\mathrm{MUC}(\mathrm{mg} / 100 \mathrm{~mL})$ was the dietary $\mathrm{NE}_{\mathrm{L}}$ $\left(\mathrm{Mcal} / \mathrm{kg} \mathrm{DM}, \mathrm{MUC}=127.6-51.2 \times \mathrm{NE}_{\mathrm{L}}, \mathrm{R}^{2}=0.85\right.$, root of the mean squared error $(\mathrm{rmse})=4.36$, $p<0.001$ ) followed by the ratio $\mathrm{CP} / \mathrm{NE}_{\mathrm{L}}$ (g/Mcal, MUC $=-14.9+0.5 \times \mathrm{CP} / \mathrm{NE}_{\mathrm{L}}, \mathrm{R}^{2}=0.83$, rmse $=$ $4.63, p<0.001)$. A meta-regression of an extended database on stall-fed dairy ewes, including the E1 and E2 experimental data $(n=44)$, confirmed the predictive value of the $\mathrm{CP} / \mathrm{NE}_{\mathrm{L}}$ ratio, which resulted as the best single predictor of $\mathrm{MUC}\left(\mathrm{MUC}=-13.7+0.5 \times \mathrm{CP} / \mathrm{NE}_{\mathrm{L}}, \mathrm{R}^{2}=0.93\right.$, rmse $=3.30, p$ $<0.001$ ), followed by dietary CP concentration (MUC $=-20.7+3.7 \times \mathrm{CP}, \mathrm{R}^{2}=0.82$, rmse $=4.89, p<$ 0.001 ). This research highlights that dietary energy content plays a pivotal role in modulating the relationship between MUC and dietary $\mathrm{CP}$ concentration in dairy sheep.
\end{abstract}

Keywords: milk composition; dietary energy; dietary protein; $\mathrm{N}$ efficiency; nutrition 


\section{Introduction}

Blood urea concentration (BUC) and milk urea concentration (MUC) are currently used as nutritional indicators in ruminants, because they are closely related to digestive tract activity [1] and endogenous ammonia production [2], the latter being associated with gluconeogenesis. Because urea is the major end product of $\mathrm{N}$ metabolism in ruminants, blood and milk urea contents are good predictors of nitrogen excretions [3]. Blood urea concentration cannot be measured routinely, because sampling requires invasive techniques and its concentration can change rapidly after meals. On the contrary, MUC is more stable and easier to sample than BUC. In dairy cows, several studies have shown that MUC is related to dietary crude protein intake (CPI), percentage of rumen degradable and undegradable protein, and the protein-to-energy ratio in diet $[4,5]$. In dairy sheep fed diets ranging from $14 \%$ to $21 \%$ of dietary CP (dry matter (DM) basis), MUC was positively and linearly related to dietary $\mathrm{CP}$ content and, to a lesser extent, to protein intake [6]. In that experiment, a relatively narrow range of energy concentration was also tested (1.55-1.65 Mcal of net energy for lactation $\left(\mathrm{NE}_{\mathrm{L}}\right)$ ), and energy was not found correlated with MUC. This contrasts with previous findings on dairy cattle [7] and goats [8]. However, in a later study [9] comparing diets with 1.40 and $1.59 \mathrm{Mcal} / \mathrm{kg} \mathrm{DM}$ of NE $\mathrm{L}_{\mathrm{L}}$ and $19-20 \%$ DM of CP fed to mid-lactation ewes, a significantly lower MUC in the ewes fed the diet with higher energy content was found.

There are no studies directly testing the effect of dietary energy concentration on MUC in dairy sheep. Because MUC reference values in lactating ewes are substantially higher compared with those in lactating goats and cows [10], it is worth exploring the effects of factors other than crude protein content and intake on MUC in lactating ewes, with particular reference to dietary energy level and source (fiber vs. non-fiber carbohydrates).

Prediction equations obtained from individual experiments can be easily compared with findings from other studies by using a meta-regression or meta-analysis approach [11]. It can be useful to check the robustness of the observed relationships and gather a more generic algorithm to be empirically used in broad contexts and at the field level or for other modeling purposes [12]. Comprehensive analysis of experimental data identified the dietary $\mathrm{CP}$ concentration as the main factor influencing MUC in dairy cows [13,14], whereas no similar efforts have been carried out for sheep.

Thus, this study was carried out with two main objectives: (i) assessing the relationships between MUC and the dietary content or intake of nutrients in dairy ewes fed diets characterized by a wide range of energy contents and carbohydrates sources; and (ii) comparing the same relationships within a meta-regression based on a broader database inclusive of other studies on stall-fed dairy sheep.

\section{Materials and Methods}

\subsection{Animals and Diets}

The study was conducted at the Bonassai experimental farm of the Agricultural Research Agency of Sardinia (AGRIS Sardegna), located in the northwest of Sardinia $\left(40^{\circ} \mathrm{N}, 32^{\circ} \mathrm{E}, 32 \mathrm{~m}\right.$ a.s.l.), in Italy. The animal protocol described below was fully in compliance with the European Union (EU) and Italian regulations on animal welfare and experimentation, and it was approved by the veterinarians responsible of the ethic and welfare control in animal experimentation of AGRIS and the University of Sassari. All measurements were taken by personnel previously trained and authorized by the institutional authorities on ethical issues both from AGRIS and the University of Sassari.

The study consisted of two feeding experiments conducted on Sarda dairy sheep during mid (in March) and late (June-July) lactation. In experiment 1 (E1), four complete pelleted diets were tested on 20 ewes, and in experiment 2 (E2), other three complete pelleted diets were tested on 15 ewes. Each experiment consisted of a seven-day preliminary period, a fourteen-day adaptation period, and a nine-day experimental period. During the preliminary period, the ewes of each experiment grazed ryegrass-based pastures. were supplemented with a mixture made of equal proportions of the relative experimental pelleted diets for four days, and were then confined in pens for three days, 
during which time they received only the mixture of the experimental pelleted diets for three days. After the preliminary period, the ewes were allocated to homogeneous groups and put in individual metabolic cages for the adaptation and experimental periods.

In E1, the 20 mid-lactation ewes were allocated to four homogeneous groups of five animals each on the basis of their days in milk (DIM; Table 1; mean \pm s.d.), milk yield (MY), body weight (BW), body condition score (BCS), age, and parity. The ewes were fed the pelleted diets ad libitum in two daily meals. The same animals were then re-randomized and used in late lactation. In E2, 15 mid-lactation ewes were assigned to three homogeneous groups of five animals each, on the basis of their DIM (Table 1), MY, BW, BCS, age, and parity. The same animals were then re-randomized and used in late lactation.

Table 1. Description of animals used in the experiments E1 and E2.

\begin{tabular}{ccccc}
\hline \multirow{2}{*}{ Item } & \multicolumn{2}{c}{ Experiment 1 } & \multicolumn{2}{c}{ Experiment 2 } \\
\cline { 2 - 4 } & Mid Lactation & Late Lactation & Mid Lactation & Late Lactation \\
\hline $\mathrm{DIM}^{1}$ (days) & $118 \pm 3$ & $222 \pm 3$ & $119 \pm 11$ & $224 \pm 10$ \\
$\mathrm{MY}^{2}$ (mL/day) & $1792 \pm 259$ & $1516 \pm 311$ & $1401 \pm 207$ & $1011 \pm 349$ \\
$\mathrm{BW}^{3}$ (kg) & $43.1 \pm 3.5$ & $47.6 \pm 4.3$ & $44.6 \pm 4.7$ & $46.2 \pm 3.4$ \\
$\mathrm{BCS}^{4}$ (0-5) & $2.3 \pm 0.18$ & $2.6 \pm 0.15$ & $2.4 \pm 0.25$ & $2.5 \pm 0.17$ \\
Age (years) & $4 \pm 1$ & $4 \pm 1$ & $5 \pm 2$ & $5 \pm 2$ \\
Parity (n.) & $3 \pm 1$ & $3 \pm 1$ & $4 \pm 2$ & $4 \pm 2$ \\
\hline
\end{tabular}

${ }^{1}$ DIM $=$ days in milk.; ${ }^{2} \mathrm{MY}=$ milk yield.; ${ }^{3} \mathrm{BW}=$ body weight.; ${ }^{4} \mathrm{BCS}=$ body condition score.

Throughout the period between the mid- and late-lactation measurements, the ewes were fed at pasture and machine-milked twice a day at 07:00 $\mathrm{h}$ and 15:00 $\mathrm{h}$ in a milking parlor. The animals were machine-milked twice a day at 07:00 $\mathrm{h}$ and 15:00 $\mathrm{h}$ inside the cages during the adaptation and experimental periods. All the animals had ad libitum access to water throughout the study.

The ingredients and the chemical composition of the diets used in E1 and E2 are summarized in Table 2. On the basis of their main ingredient, the following diets were tested: $\mathrm{CF}=$ corn flakes, $\mathrm{BM}$ = barley meal, $\mathrm{BP}=$ beet pulp, and $\mathrm{CC}=$ corn cobs, in E1; and $\mathrm{CM}=$ corn meal, $\mathrm{AA}=$ dehydrated alfalfa, and $\mathrm{SH}=$ soybean hulls, in E2. All the diets contained dehydrated alfalfa as a common base and other ingredients (barley meal, corn flakes, corn meal, beet pulp, corn cobs, corn germ, corn gluten meal, soybean hulls, wheat middlings, minerals, and vitamins) were added in order to obtain different fiber (neutral detergent fiber (NDF), acid detergent fiber (ADF), and acid detergent lignin (ADL)) and energy contents, while keeping $\mathrm{CP}$ concentrations similar.

Table 2. Ingredients and chemical composition of the experimental diets.

\begin{tabular}{|c|c|c|c|c|c|c|c|}
\hline \multirow{2}{*}{ Item } & \multicolumn{4}{|c|}{ Experiment 1} & \multicolumn{3}{|c|}{ Experiment 2} \\
\hline & $\mathrm{CF}^{1}$ & BM & BP & $\mathrm{CC}$ & $\mathrm{CM}$ & AA & SH \\
\hline Ingredients & & & & & & & \\
\hline Barley meal (\% DM) & & 47.0 & & & & & \\
\hline Corn flakes (\% DM) & 51.6 & & & & & & \\
\hline Corn meal (\% DM) & & & & & 59.3 & & \\
\hline Dehydrated alfalfa (\% DM) & 27.0 & 28.0 & 26.0 & 26.6 & 26.7 & 89.4 & 26.2 \\
\hline Beet pulp (\% DM) & & & 40.9 & & & & \\
\hline Corn cobs $(\% \mathrm{DM})$ & & & & 32.5 & & & \\
\hline Corn germ (\% DM) & 6.4 & 12.9 & 20.0 & 20.0 & & & \\
\hline Corn gluten meal (\% DM) & 8.0 & 1.7 & 1.9 & 5.8 & 8.2 & & 5.5 \\
\hline Soybean hulls (\% DM) & & & & & & & 62.3 \\
\hline Wheat middlings (\% DM) & & & 6.1 & 10.0 & & 5.0 & \\
\hline Minerals and vitamins (\% DM) & 7.0 & 7.0 & 5.1 & 5.1 & 5.8 & 5.6 & 6.0 \\
\hline
\end{tabular}


Table 2. Cont.

\begin{tabular}{|c|c|c|c|c|c|c|c|}
\hline \multirow{2}{*}{ Item } & \multicolumn{4}{|c|}{ Experiment 1} & \multicolumn{3}{|c|}{ Experiment 2} \\
\hline & $\mathrm{CF}^{1}$ & BM & $\mathbf{B P}$ & $\mathrm{CC}$ & $\mathbf{C M}$ & AA & SH \\
\hline \multicolumn{8}{|l|}{ Chemical composition $^{2}$} \\
\hline $\mathrm{CP}(\% \mathrm{DM})$ & 18.7 & 18.1 & 17.9 & 19.8 & 18.0 & 19.7 & 17.5 \\
\hline $\mathrm{EE}(\% \mathrm{DM})$ & 2.7 & 3.1 & 3.3 & 4.4 & 3.0 & 2.6 & 2.5 \\
\hline Ash (\% DM) & 8.1 & 9.3 & 8.3 & 8.5 & 7.3 & 11.2 & 9.0 \\
\hline NDF (\% DM) & 28.5 & 33.2 & 44.9 & 45.8 & 23.9 & 45.6 & 51.9 \\
\hline $\mathrm{ADF}(\% \mathrm{DM})$ & 14.2 & 16.3 & 21.4 & 22.2 & 12.4 & 29.2 & 36.0 \\
\hline ADL (\% DM) & 2.8 & 3.0 & 3.3 & 3.7 & 2.1 & 6.0 & 2.8 \\
\hline $\operatorname{NFC}(\% \mathrm{DM})^{3}$ & 47.3 & 41.0 & 31.8 & 26.1 & 51.2 & 25.1 & 23.6 \\
\hline WSC (\% DM) & 3.7 & 3.7 & 4.5 & 3.6 & 3.3 & 4.3 & 3.2 \\
\hline starch (\% DM) & 28.8 & 25.2 & 8.0 & 12.4 & 35.6 & 7.1 & 3.2 \\
\hline $\mathrm{Ca}(\% \mathrm{DM})$ & 1.18 & 1.42 & 1.25 & 0.88 & 0.78 & 1.62 & 1.17 \\
\hline $\mathrm{P}(\% \mathrm{DM})$ & 0.55 & 0.45 & 0.50 & 0.52 & 0.49 & 0.51 & 0.55 \\
\hline $\mathrm{Cl}(\% \mathrm{DM})$ & 0.62 & 0.64 & 0.60 & 0.64 & 0.62 & 0.96 & 0.63 \\
\hline $\mathrm{K}(\% \mathrm{DM})$ & 0.98 & 1.22 & 0.90 & 1.14 & 0.97 & 2.43 & 1.63 \\
\hline $\mathrm{Mg}(\% \mathrm{DM})$ & 0.25 & 0.30 & 0.33 & 0.31 & 0.22 & 0.30 & 0.27 \\
\hline $\mathrm{S}(\% \mathrm{DM})$ & 0.60 & 0.53 & 0.57 & 0.58 & 0.64 & 0.58 & 0.56 \\
\hline $\mathrm{Na}(\% \mathrm{DM})$ & 0.62 & 0.74 & 0.72 & 0.58 & 0.60 & 0.62 & 0.60 \\
\hline $\mathrm{NE}_{\mathrm{L}}$ mid lactation (Mcal/kg DM) & 1.80 & 1.75 & 1.78 & 1.52 & 1.82 & 1.32 & 1.49 \\
\hline $\mathrm{NE}_{\mathrm{L}}$ late lactation $(\mathrm{Mcal} / \mathrm{kg} \mathrm{DM})$ & 1.88 & 1.69 & 1.73 & 1.53 & 1.76 & 1.20 & 1.44 \\
\hline $\mathrm{CP} / \mathrm{NE}_{\mathrm{L}}$ mid lactation & 104 & 103 & 101 & 130 & 99 & 149 & 118 \\
\hline $\mathrm{CP} / \mathrm{NE}_{\mathrm{L}}$ late lactation & 99 & 107 & 103 & 129 & 103 & 165 & 123 \\
\hline \multicolumn{8}{|l|}{ Protein fractions ${ }^{4}(\% \mathrm{DM})$} \\
\hline A & 2.9 & 3.5 & 3.5 & 4.4 & 3.3 & 4.7 & 3.0 \\
\hline $\mathrm{B}_{1}$ & 1.3 & 1.7 & 1.3 & 1.3 & 0.7 & 2.4 & 1.4 \\
\hline $\mathrm{B}_{2}$ & 9.1 & 8.2 & 6.8 & 9.5 & 10.6 & 8.4 & 8.6 \\
\hline $\mathrm{B}_{3}$ & 3.4 & 3.2 & 4.4 & 2.9 & 1.9 & 2.7 & 2.6 \\
\hline $\mathrm{C}$ & 1.9 & 1.5 & 1.8 & 1.7 & 1.5 & 1.5 & 1.9 \\
\hline PDIN $^{5}(\%$ DM $)$ & 132 & 104 & 100 & 112 & 137 & 114 & 120 \\
\hline PDIE $^{6}(\%$ DM) & 137 & 106 & 107 & 109 & 147 & 94 & 129 \\
\hline
\end{tabular}

${ }^{1}$ Diets (based on main ingredients): $\mathrm{CF}=$ corn flakes; $\mathrm{BM}=$ barley meal; $\mathrm{BP}=$ beet pulp; $\mathrm{CC}=$ corn cobs; $\mathrm{CM}$ = corn meal; $\mathrm{AA}=$ dehydrated alfalfa; $\mathrm{SH}=$ soybean hulls.; ${ }^{2} \mathrm{DM}=$ dry matter; $\mathrm{CP}=$ crude protein; $\mathrm{EE}=$ ether extract; $\mathrm{NDF}=$ neutral detergent fiber; $\mathrm{ADF}=$ acid detergent fiber; $\mathrm{ADL}=$ acid detergent lignin; $\mathrm{NFC}=$ non-fiber carbohydrates; WSC $=$ water soluble carbohydrates; $\mathrm{NE}_{\mathrm{L}}=$ net energy for lactation.; ${ }^{3} \mathrm{NFC}=100-(\mathrm{NDF}-\mathrm{NDIP})$ $-\mathrm{CP}-\mathrm{EE}-\mathrm{Ash}$, where NDIP = neutral detergent insoluble protein $(\% \mathrm{DM}) .{ }^{4}$ protein fractions: $\mathrm{A}=$ non-protein nitrogen (NPN); $B_{1}=$ buffer soluble true protein; $B_{2}=$ buffer insoluble protein - neutral detergent insoluble protein; $\mathrm{B}_{3}=$ neutral detergent insoluble protein - acid detergent insoluble protein; $\mathrm{C}=$ acid detergent insoluble protein.; ${ }^{5}$ PDIN balance $(\mathrm{g} /$ day $)=$ PDIN allowance $(\mathrm{g} /$ day $)-$ PDIN requirement $\left(\mathrm{g} /\right.$ day).; ${ }^{6}$ PDIN balance $(\%)=($ PDIN allowance $(\mathrm{g} /$ day $)-$ PDIN requirement $(\mathrm{g} /$ day $)) /$ PDIN requirement $(\mathrm{g} /$ day $) \times 100$.

The energy content of the diets was calculated as net energy for lactation $\left(\mathrm{NE}_{\mathrm{L}}\right)$ on the basis of total digestible nutrient (TDN, \% DM) [15]:

$$
\mathrm{NE}_{\mathrm{L}}(\mathrm{Mcal} / \mathrm{kg} \mathrm{DM})=0.0245 \mathrm{TDN}-0.12,
$$

whereas TDN was calculated as follows:

$$
\mathrm{TDN}(\% \mathrm{DM})=(\mathrm{dCPI}+\mathrm{dNDFI}+\mathrm{dNFCI}+\mathrm{dEEI} \times 2.25) / \mathrm{DMI} \times 100
$$

where $\mathrm{dCPI}=$ digestible $\mathrm{CP}$ intake $(\mathrm{g} /$ day $), \mathrm{dNDFI}=$ digestible NDF intake $(\mathrm{g} /$ day $), \mathrm{dNFCI}=$ digestible non-fiber carbohydrates (NFC) intake (g/day), dEEI = digestible ether extract intake (g/day), and DMI $=$ dry matter intake $(\mathrm{g} /$ day). The data on intake of digestible nutrients measured in vivo and used in the above equations are reported in [16]. In order to prevent acidosis in late lactation, due to a possible uneven feeding pattern associated with the high diurnal temperature typical of the late-lactation period (June-July), $10 \mathrm{~g} /$ day per head of sodium bicarbonate were added to all the diets. 


\subsection{Measurements}

In both experiments, the individual intake was measured by weighing the offered diets and the corresponding orts $24 \mathrm{~h}$ after the first daily meal during the experimental period. Samples of feed on offer were collected once a week and stored until analyses. Individual milk yield was measured three times during the experimental period, and individual milk samples, at the morning and afternoon milking, were also taken. The concentration of protein digestible in the intestine, when energy or nitrogen is not limiting rumen microbial growth (PDIN and PDIE), was calculated for each diet using tabular values [17]. The requirements of dairy sheep in terms of protein digestible in the intestine (PDI) were estimated with the equation of [18], and PDIN balance was then estimated as the difference between intake and requirements (g/day) and as the ratio between PDI balance ( $\mathrm{g} /$ day) and PDI requirements $(\mathrm{g} /$ day), expressed as a percentage.

\subsection{Chemical Analyses}

Feed samples were analyzed for DM; ash; CP; ether extract (EE, [19]); ash-free fiber fractions as NDF, without the use of sodium sulfite, ADF, and ADL [20]; CP fractions [21]; and starch (polarimetric method, [22]). The non-fiber carbohydrates (NFC) concentration was calculated as [100 - (NDF NDIP) - CP - EE - ash], where NDIP = neutral detergent insoluble protein. Individual milk samples were analyzed for fat, true protein, and lactose using the infrared method (Milkoscan 4000, Foss Electric, Hillerød, Denmark) and urea by a colorimetric method (ChemSpec 150, Bentley Instruments Inc., Chaska, MN, USA; Broutin, 2000) calibrated by differential pH measurements (CL10-Eurochem, Rome, Italy).

\subsection{Statistical Analysis}

To target the first objective of the study (assessment of the effect of dietary energy on milk urea concentration), the results of the experiments were averaged by dietary group and physiological stage, and treatment means $(n=14)$ of the two experiments were pooled and used to study the relationships between dietary variables, nutrient intake, and MUC, as detailed below. First, values of MUC were regressed against dietary concentration and intake of nutrients, as well as PDIN balance, using a simple linear regression model:

$$
\mathrm{Yi}=\mathrm{B}_{0}+\mathrm{C}_{0} \mathrm{X}_{\mathrm{i}}+\mathrm{e}_{\mathrm{i}}
$$

where $\mathrm{B}_{0}=$ intercept, $\mathrm{C}_{0}=$ regression coefficient, $\mathrm{Xi}=$ independent variable, and ei $=$ random error. Second, a stepwise regression analysis was performed to verify if any multiple regression model could fit better than simple regression models to predict MUC. All dietary variables already quoted were tested using $p<0.15$ as entry and stay probability thresholds. Because no variables were kept in the model, except for the content of dietary energy, no further attempts were made to test multiple regression models.

To pursue the second objective of the study (meta-analysis of the available literature on stall-fed dairy sheep) an extended dataset was made by adding to the current experiment results data from other experiments where dietary $\mathrm{CP}$ and energy intake and or their contents in sheep diet were related to milk urea. The search of relevant papers was done using Scopus with the keywords "sheep and nutrition and milk urea", exploring all the scientific literature available to those engines in the time range of 1970-2019. Overall, the search resulted in 25 papers in the Scopus database, including primary and secondary documents, most of which were not relevant due to the focus on non-nutritional aspects or to the lack of accurate information on $\mathrm{CP}$ and energy intake (mostly grazing studies) or because urea was measured erratically or only in sheep plasma. Furthermore, all experiments that included diets containing tannins were discarded from the dataset because tannins are known for of their effects in modulating the use of dietary proteins. Low to moderate levels of tannins in the diet may actually reduce the protein degradation in the rumen and increase amino acid flow to the small intestine, while high levels can reduce voluntary feed intake and nutrient digestibility. At the end of this screening 
process, only six studies on stall-fed dairy sheep reported in the literature were selected [6,9,23-26], and their treatment means merged to those obtained in our study to form the extended dataset.

The relationships derived from the extended dataset were calculated using two statistical models: (1) simple linear regression models and (2) meta-analytical mixed models [27], which included the regressors as fixed effects and the "study effect" (Exp) as random effect [11]. In particular, the implemented model was as follows:

$$
\mathrm{Y}_{\mathrm{ij}}=\mathrm{A}_{0}+\mathrm{B}_{0} \mathrm{X}_{\mathrm{ij}}+\operatorname{Exp}_{\mathrm{i}}+\mathrm{b}_{\mathrm{i}} \mathrm{X}_{\mathrm{ij}}+\mathrm{e}_{\mathrm{ij}}
$$

where $\mathrm{A}_{0}=$ overall intercept, $\mathrm{B}_{0}=$ overall regression coefficient, $\mathrm{X}_{\mathrm{ij}}=$ independent variable, $\operatorname{Exp}_{\mathrm{i}}=$ random effect of the study on the intercept, $b_{i}=$ random effect of the study on the regression slope and $\mathrm{e}_{\mathrm{ij}}=$ random error.

\section{Results}

\subsection{Composition of the Diets}

The composition of the diets (Table 2) corresponded to the planned values, except for $\mathrm{CP}$ concentration, which unexpectedly showed a range of variability, although it was limited to about $\pm 5 \%$ of the average within the trial (range of CP: $17.9-19.8 \%$ in E1 and 17.5-19.7\% in E2, DM basis). In contrast, the range of NDF (28.5-45.8\% in E1, 23.9-51.9\% in E2, DM basis) and starch concentration (8-28.8\% in E1, 3.2-35.6\% in E2, DM basis) was very broad. Therefore, as planned, the diets were characterized by contrasting levels of dietary energy, spanning across the two experiments from a minimum of 1.2 Mcal of $\mathrm{NE}_{\mathrm{L}} / \mathrm{kg} \mathrm{DM}$ to a maximum of $1.9 \mathrm{Mcal}$ of $\mathrm{NE}_{\mathrm{L}} / \mathrm{kg} \mathrm{DM}$.

\subsection{Animal Data}

Mean values of the animal data used in the subsequent regression analysis and their ranges are displayed in Table 3.

\subsection{Results of E1 and E2}

Significant negative and linear relationships were found between dietary NFC or starch and MUC $\left(R^{2}=0.39, p<0.01\right.$; Table 4$)$. The strength of the relationship markedly increased when MUC was regressed against dietary $\mathrm{NE}_{\mathrm{L}}\left(\mathrm{R}^{2}=0.85, p<0.01\right)$, which was the best single predictor of MUC. 
Table 3. Intake of dry matter and nutrient, PDIN balance, milk yield and composition, and milk urea concentration (mean and range) in mid- and late-lactation dairy ewes in experiments 1 and 2.

\begin{tabular}{|c|c|c|c|c|c|c|c|c|c|c|c|c|c|c|c|}
\hline \multirow{3}{*}{ Item $^{2}$} & & \multicolumn{8}{|c|}{ Experiment 1} & \multicolumn{6}{|c|}{ Experiment 2} \\
\hline & & \multicolumn{4}{|c|}{ Mid Lactation } & \multicolumn{4}{|c|}{ Late Lactation } & \multicolumn{3}{|c|}{ Mid Lactation } & \multicolumn{3}{|c|}{ Late Lactation } \\
\hline & & $\mathrm{CF}^{1}$ & BM & BP & $\mathrm{CC}$ & $\mathrm{CF}$ & BM & BP & $\mathrm{CC}$ & $\mathrm{CM}$ & AA & SH & $\mathrm{CM}$ & AA & SH \\
\hline \multirow{3}{*}{ DMI (g/day) } & Mean & 1870 & 1849 & 2055 & 2602 & 1295 & 1752 & 1992 & 2182 & 1717 & 2196 & 2634 & 890 & 1903 & 1603 \\
\hline & Min & 1262 & 1674 & 1585 & 2159 & 1192 & 1024 & 1701 & 1863 & 1413 & 1933 & 2136 & 582 & 1701 & 1230 \\
\hline & $\operatorname{Max}$ & 2401 & 2238 & 2588 & 3392 & 1367 & 2423 & 2386 & 2548 & 2096 & 2438 & 3175 & 1211 & 2148 & 1879 \\
\hline \multirow{3}{*}{ CPI (g/day) } & Mean & 349 & 334 & 367 & 516 & 241 & 317 & 356 & 433 & 310 & 432 & 461 & 160 & 375 & 280 \\
\hline & Min & 235 & 302 & 283 & 428 & 222 & 185 & 304 & 369 & 255 & 381 & 374 & 105 & 335 & 215 \\
\hline & $\operatorname{Max}$ & 448 & 405 & 463 & 673 & 255 & 438 & 427 & 506 & 378 & 480 & 556 & 218 & 423 & 329 \\
\hline \multirow{3}{*}{$\mathrm{NE}_{\mathrm{L}} \mathrm{I}$ (Mcal/day) } & Mean & 3.37 & 3.23 & 3.65 & 3.96 & 2.43 & 2.97 & 3.46 & 3.34 & 3.13 & 2.91 & 3.93 & 1.56 & 2.27 & 2.28 \\
\hline & Min & 2.24 & 2.97 & 2.89 & 3.29 & 2.25 & 1.66 & 2.93 & 2.84 & 2.59 & 2.53 & 3.38 & 1.11 & 1.98 & 2.05 \\
\hline & $\operatorname{Max}$ & 4.42 & 3.90 & 4.56 & 5.13 & 2.61 & 4.10 & 4.20 & 3.86 & 3.82 & 3.27 & 4.68 & 2.27 & 2.48 & 2.50 \\
\hline \multirow{4}{*}{ PDIN balance $(\mathrm{g} / \text { day })^{3}$} & Mean & 63.1 & 27.7 & 33.1 & 130.9 & 60.7 & 48.7 & 70.3 & 122.1 & 89.2 & 117.9 & 140.7 & -31.2 & 112.5 & 81.4 \\
\hline & Min & 36.7 & -9.5 & 16.6 & 104.0 & 40.1 & 10.2 & 31.3 & 76.6 & 52.6 & 99.1 & 124.5 & -25.5 & 75.8 & -19.1 \\
\hline & $\operatorname{Max}$ & 95.6 & 48.6 & 48.9 & 178.0 & 92.4 & 92.6 & 103.7 & 104.1 & 136.3 & 152.7 & 164.8 & 102.6 & 125.5 & 115.9 \\
\hline & Mean & 33.7 & 18.3 & 18.9 & 80.5 & 61.0 & 34.8 & 60.4 & 103.5 & 64.4 & 91.1 & 84.1 & 48.3 & 116.0 & 79.1 \\
\hline \multirow[t]{2}{*}{ PDIN balance (\%) ${ }^{4}$} & Min & 26.6 & -4.6 & 11.7 & 72.6 & 29.6 & 10.6 & 20.5 & 57.8 & 37.4 & 60.9 & 63.0 & -22.4 & 57.0 & 14.8 \\
\hline & Max & 43.3 & 27.1 & 23.5 & 87.7 & 107.6 & 58.1 & 111.9 & 160.7 & 107.3 & 121.9 & 122.4 & 163.3 & 163.3 & 138.7 \\
\hline \multirow{3}{*}{ Milk (g/day) } & Mean & 1678 & 1393 & 1541 & 1445 & 728 & 934 & 990 & 899 & 1181 & 1075 & 1584 & 498 & 732 & 746 \\
\hline & Min & 880 & 939 & 1084 & 1072 & 393 & 643 & 343 & 503 & 813 & 864 & 1052 & 249 & 386 & 422 \\
\hline & $\operatorname{Max}$ & 2235 & 2133 & 1897 & 1782 & 1098 & 1218 & 1372 & 1242 & 1498 & 1450 & 2405 & 928 & 1126 & 986 \\
\hline \multirow{3}{*}{ Fat $(\%)$} & Mean & 4.0 & 4.3 & 4.5 & 6.0 & 4.2 & 4.9 & 4.7 & 6.0 & 4.3 & 6.4 & 5.6 & 4.9 & 4.8 & 6.0 \\
\hline & Min & 3.3 & 3.7 & 3.8 & 4.0 & 3.9 & 4.1 & 3.7 & 4.9 & 3.1 & 5.5 & 5.0 & 3.6 & 4.2 & 3.8 \\
\hline & Max & 5.1 & 5.3 & 5.4 & 7.7 & 4.8 & 5.4 & 5.6 & 7.0 & 6.1 & 7.9 & 7.1 & 6.6 & 5.1 & 8.0 \\
\hline \multirow{3}{*}{ Protein $(\%)$} & Mean & 5.1 & 5.4 & 5.1 & 4.9 & 5.4 & 5.7 & 5.3 & 5.2 & 5.3 & 5.0 & 5.0 & 5.8 & 4.8 & 5.4 \\
\hline & Min & 4.7 & 4.7 & 4.8 & 4.1 & 4.8 & 5.1 & 4.5 & 4.4 & 4.2 & 4.5 & 4.7 & 3.9 & 4.6 & 4.8 \\
\hline & $\operatorname{Max}$ & 6.0 & 6.0 & 5.5 & 6.0 & 6.0 & 6.2 & 6.3 & 6.9 & 7.1 & 5.8 & 5.9 & 6.9 & 5.4 & 6.6 \\
\hline \multirow{3}{*}{ Lactose (\%) } & Mean & 5.1 & 5.0 & 4.9 & 4.8 & 4.4 & 4.8 & 4.5 & 4.6 & 4.4 & 4.6 & 4.7 & 3.5 & 4.3 & 4.3 \\
\hline & Min & 4.8 & 4.8 & 4.8 & 4.7 & 4.2 & 4.5 & 4.0 & 4.2 & 4.0 & 4.5 & 4.2 & 2.8 & 3.5 & 3.8 \\
\hline & Max & 5.3 & 5.2 & 5.1 & 5.0 & 4.8 & 5.1 & 4.8 & 5.1 & 4.9 & 4.9 & 5.1 & 4.4 & 5.0 & 4.7 \\
\hline \multirow{3}{*}{ MUC (mg/dL) } & Mean & 33.5 & 36.2 & 34.7 & 48.4 & 38.4 & 46.1 & 38.8 & 44.9 & 33.3 & 57.2 & 43.5 & 37.7 & 72.8 & 57.9 \\
\hline & Min & 27.6 & 30.2 & 30.4 & 37.8 & 30.8 & 39.4 & 31.4 & 35.7 & 23.0 & 43.7 & 39.8 & 28.5 & 57.1 & 52.2 \\
\hline & Max & 42.6 & 46.8 & 40.8 & 55.5 & 43.7 & 50.7 & 48.5 & 51.0 & 44.8 & 67.5 & 51.3 & 44.1 & 81.5 & 67.8 \\
\hline
\end{tabular}

${ }^{1}$ Diets (based on main ingredients): $\mathrm{CF}=$ corn flakes; $\mathrm{BM}=$ barley meal; $\mathrm{BP}=$ beet pulp; $\mathrm{CC}=$ corn cobs; $\mathrm{CM}=$ corn meal; $\mathrm{AA}=$ dehydrated alfalfa; $\mathrm{SH}=$ soybean hulls.; ${ }^{2} \mathrm{DMI}=$ dry matter intake; $\mathrm{CPI}=$ crude protein intake; $\mathrm{NE}_{\mathrm{L}} \mathrm{I}=$ net energy for lactation intake; $\mathrm{PDIN}$ = protein digestible in the intestine when energy is not limiting rumen microbial growth; MUC $=$ milk urea concentration. $;{ }^{3}$ PDIN balance $(\mathrm{g} /$ day $)=$ PDIN allowance $(\mathrm{g} /$ day $)-$ PDIN requirement $(\mathrm{g} /$ day $) . ;{ }^{4}$ PDIN balance $(\%)=($ PDIN allowance $(\mathrm{g} /$ day $)-$ PDIN requirement

$(\mathrm{g} /$ day $)) / \mathrm{PDIN}$ requirement $(\mathrm{g} /$ day $) \times 100$. 
Table 4. Prediction of milk urea concentration (MUC, $\mathrm{Y}, \mathrm{mg} / \mathrm{dL}$ ) according to linear fixed effects regression models based on diet composition or nutrient intake as independent regression variables using pooled data from experiments 1 and 2 conducted on mid- and late-lactation dairy sheep.

\begin{tabular}{|c|c|c|c|c|c|c|c|c|c|c|}
\hline \multirow{2}{*}{$x^{2}$} & \multicolumn{3}{|c|}{ Intercept } & \multicolumn{3}{|c|}{ Slope } & \multicolumn{4}{|c|}{ Whole Equation ${ }^{1}$} \\
\hline & $\mathbf{B}_{0}$ & s.e. & $p<$ & $\mathrm{C}_{0}$ & s.e. & $p<$ & $\underset{5}{\text { rmse }}$ & $\mathrm{CV}^{6}$ & $\mathbf{R}^{2}$ & $p<$ \\
\hline $\mathrm{CP}(\% \mathrm{DM})$ & -68.4 & 61.6 & 0.29 & 6.1 & 3.3 & 0.09 & 10.46 & 23.5 & 0.15 & 0.09 \\
\hline $\mathrm{A}(\% \mathrm{DM})$ & 4.16 & 14.5 & 0.77 & 11.1 & 3.9 & 0.01 & 9.19 & 20.6 & 0.35 & 0.015 \\
\hline $\mathrm{B}_{1}(\% \mathrm{DM})$ & 19.7 & 7.1 & 0.02 & 17.1 & 4.7 & 0.003 & 8.14 & 18.3 & 0.49 & 0.003 \\
\hline $\mathrm{A}+\mathrm{B}_{1}(\% \mathrm{DM})$ & 1.3 & 11.1 & 0.91 & 8.5 & 2.1 & 0.002 & 7.79 & 17.5 & 0.53 & 0.001 \\
\hline NDF (\% DM) & 19.3 & 10.7 & 0.09 & 0.6 & 0.3 & 0.03 & 9.70 & 21.8 & 0.27 & 0.03 \\
\hline ADF (\% DM) & 23.9 & 6.8 & 0.004 & 0.9 & 0.3 & 0.007 & 8.68 & 14.5 & 0.42 & 0.007 \\
\hline ADL (\% DM) & 19.6 & 6.1 & 0.007 & 7.4 & 1.7 & 0.001 & 0.61 & 16.7 & 0.57 & 0.001 \\
\hline NFC (\% DM) & 68.9 & 8.2 & 0.001 & -0.7 & 0.2 & 0.009 & 8.85 & 19.9 & 0.39 & 0.009 \\
\hline starch (\% DM) & 58.9 & 5.3 & 0.001 & -0.6 & 0.2 & 0.01 & 8.88 & 19.9 & 0.39 & 0.01 \\
\hline NFCI (g/day) & 76.1 & 11.2 & 0.001 & -0.05 & 0.02 & 0.01 & 9.09 & 20.4 & 0.36 & 0.01 \\
\hline starchI (g/day) & 64.5 & 5.9 & 0.001 & -0.05 & 0.01 & 0.003 & 8.19 & 19.4 & 0.48 & 0.003 \\
\hline $\mathrm{NE}_{\mathrm{L}}(\mathrm{Mcal} / \mathrm{kg} \mathrm{DM})$ & 127.6 & 9.6 & 0.001 & -51.2 & 5.8 & 0.001 & 4.36 & 9.8 & 0.85 & 0.001 \\
\hline $\mathrm{CP} / \mathrm{NE}_{\mathrm{L}}(\mathrm{g} / \mathrm{Mcal})$ & -14.9 & 7.4 & 0.07 & 0.5 & 0.06 & 0.001 & 4.63 & 10.4 & 0.83 & 0.001 \\
\hline PDIN balance (g/day) ${ }^{3}$ & 32.2 & 6.4 & 0.001 & 0.15 & 0.07 & 0.056 & 10.10 & 22.6 & 0.27 & 0.056 \\
\hline PDIN balance (\%) ${ }^{4}$ & 26.9 & 5.1 & 0.001 & 0.28 & 0.07 & 0.003 & 7.99 & 17.96 & 0.54 & 0.003 \\
\hline
\end{tabular}

${ }^{1}$ Regressions based on experimental treatment means.; ${ }^{2} \mathrm{X}=$ Independent regression variable; $\mathrm{CP}=$ crude protein; $\mathrm{B}_{0}$ is the intercept, $\mathrm{C}_{0}$ is the regression coefficient, $\mathrm{A}=$ non-protein nitrogen (NPN); $\mathrm{B}_{1}=$ buffer soluble true protein; $\mathrm{NDF}=$ neutral detergent fiber; $\mathrm{ADF}=$ acid detergent fiber; $\mathrm{ADL}=$ acid detergent lignin; $\mathrm{NFC}=$ non-fiber carbohydrates; $\mathrm{NFCI}=\mathrm{NFC}$ intake; starchI = starch intake; $\mathrm{NE}_{\mathrm{L}}=$ net energy for lactation; $\mathrm{PDIN}$ = protein digestible in the intestine, when energy is not limiting rumen microbial growth.; ${ }^{3}$ PDIN balance (g/day) = PDIN intake (g/day) - PDIN requirement $(\mathrm{g} /$ day $) ;{ }^{4}$ PDIN balance $(\%)=($ PDIN intake $(\mathrm{g} /$ day $)-$ PDIN requirement $(\mathrm{g} /$ day $)) /$ PDIN requirement $(\mathrm{g} /$ day $) \times 100 ;{ }^{5} \mathrm{rmse}=$ root of the mean squared error; ${ }^{6} \mathrm{CV}=$ coefficient of variation.

The dietary $\mathrm{CP}$ content tended to be related to $\mathrm{MUC}(p=0.09)$. In contrast, the ratio $\mathrm{CP} / \mathrm{NE}_{\mathrm{L}}$ was strongly related to MUC, performing similarly to dietary $\mathrm{NE}_{\mathrm{L}}\left(\mathrm{R}^{2}=0.83, p<0.001\right)$. The sum of $\mathrm{A}+\mathrm{B} 1$ protein fractions was more closely related to MUC $\left(R^{2}=0.53\right)$ than the single fractions $B 1\left(R^{2}=0.49\right)$ or A $\left(R^{2}=0.35\right)$.

Significant relationships were found when MUC was regressed against the fiber fractions, among which ADL showed the highest coefficient of determination $\left(R^{2}=0.57\right)$, followed by ADF $\left(R^{2}=0.42\right)$ and NDF $\left(R^{2}=0.27\right)$. The relationships between NE $I$ or CPI and MUC were not significant (data not shown). NDFI was not related to MUC either. On the contrary, NFCI had a weak but significant negative relationship with MUC $\left(\mathrm{R}^{2}=0.36, p<0.01\right)$, which was also related negatively to starch intake (starchI, $R^{2}=0.48, p<0.003$ ). A linear positive relationship was found between PDIN balance, expressed as $\mathrm{g} /$ day, and MUC $\left(\mathrm{R}^{2}=0.27, p<0.056\right)$. The strength of the relationship markedly increased when MUC was regressed against PDIN balance, expressed as \% of PDIN requirement $\left(R^{2}=0.54\right.$, $p<0.003)$.

\subsection{Results of the Meta-Analyses}

The extended database on stall-fed sheep had a total of 44 dietary treatments, characterized by a wide range of dietary $\mathrm{CP}$ and energy contents $\left(\mathrm{CP}\right.$ : from $12.3 \%$ to $24.6 \% \mathrm{DM}$; $\mathrm{NE}_{\mathrm{L}}$ : from 1.20 to 1.88 $\mathrm{Mcal} / \mathrm{kg} \mathrm{DM}$ ). The diets were based on pelleted concentrates, hay and concentrates, and fresh forages clipped at a height of $5 \mathrm{~cm}$ above the soil surface. The trend of MUC and the variation of dietary $\mathrm{CP}$, $\mathrm{NE}_{\mathrm{L}}$, or $\mathrm{CP} / \mathrm{NE}_{\mathrm{L}}$, considering each experiment separately, are depicted in Figures 1-3, respectively. 


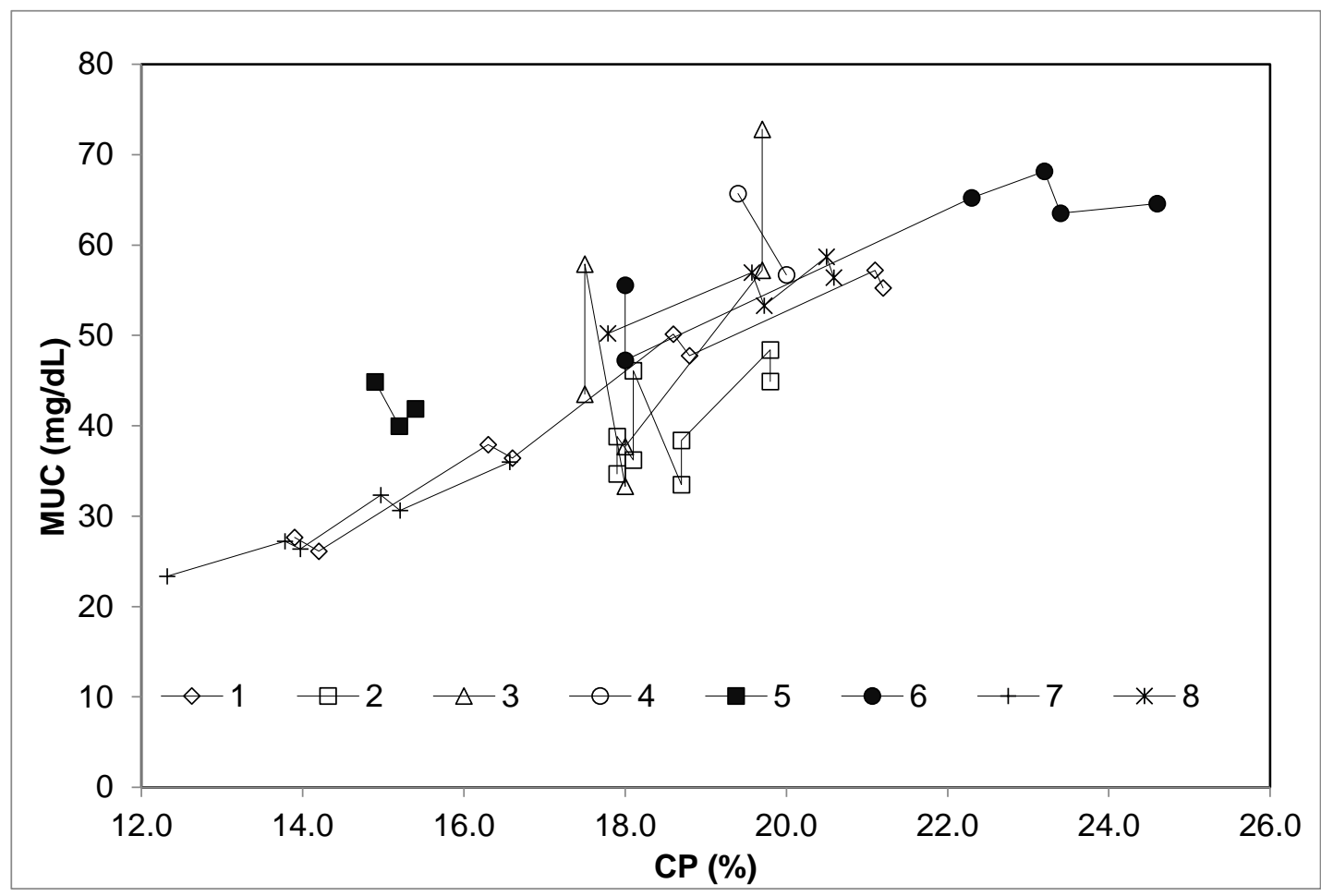

Figure 1. Relationship between milk urea concentration (MUC; mg/dL) and crude protein (CP; \% DM) considering each single experiment on dairy sheep of the meta-analysis database separately. $1=[6] ; 2$ =E1, present study; $3=$ E2, present study; $4=[9] ; 5=[24] ; 6=[23] ; 7=[26] ;$ and $8=[25]$.

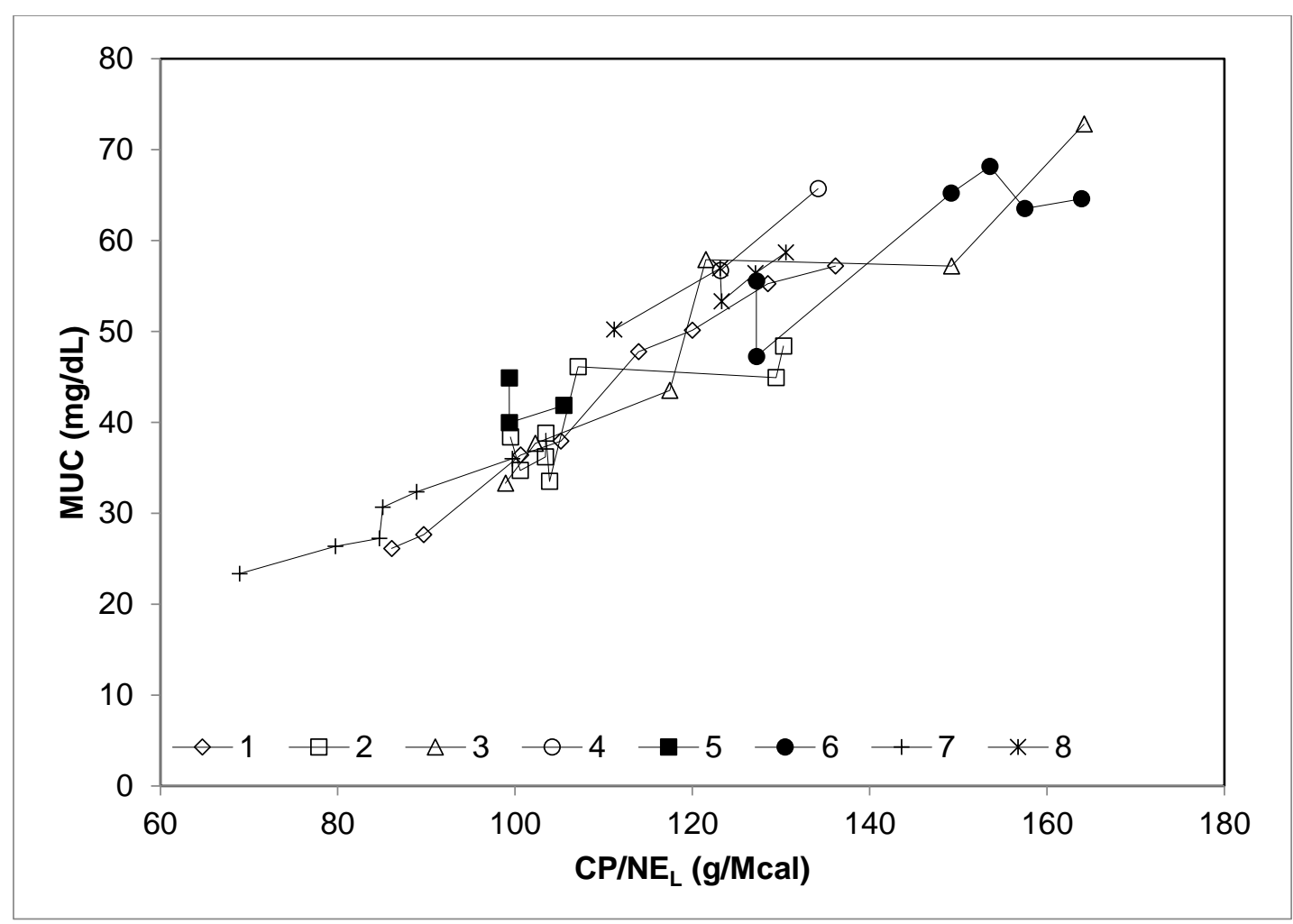

Figure 2. Relationship between milk urea concentration (MUC; $\mathrm{mg} / \mathrm{dL}$ ) and the ratio among crude protein $(\mathrm{CP})$ and net energy for lactation $\left(\mathrm{CP} / \mathrm{NE}_{\mathrm{L}}, \mathrm{g} / \mathrm{Mcal}\right)$ considering each single experiment on dairy sheep of the meta-analysis database separately. $1=[6] ; 2=\mathrm{E} 1$, present study; $3=\mathrm{E} 2$, present study; 4 $=[9] ; 5=[24] ; 6=[23] ; 7=[26] ;$ and $8=[25]$. 


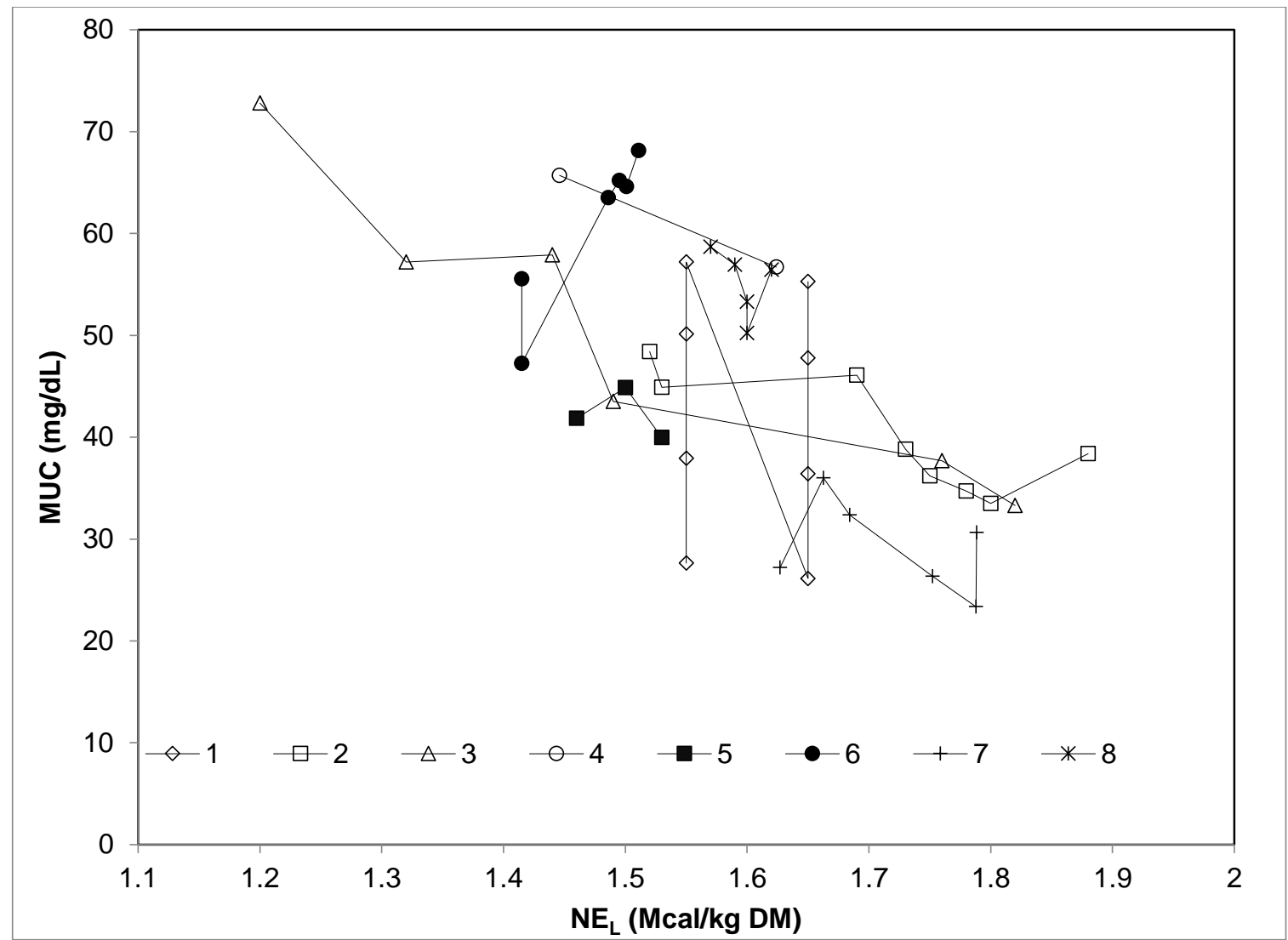

Figure 3. Relationship between milk urea concentration (MUC, $\mathrm{mg} / \mathrm{dL}$ ) and net energy for lactation $\left(\mathrm{NE}_{\mathrm{L}}, \mathrm{Mcal} / \mathrm{kg} \mathrm{DM}\right)$ considering each single experiment on dairy sheep of the meta-analysis database separately. $1=[6] ; 2=$ E1, present study; $3=$ E2, present study; $4=[9] ; 5=[24] ; 6=[23] ; 7=[26] ;$ and $8=[25]$.

The results of regression meta-analyses are shown in Table 5.

Table 5. Relationship between milk urea concentration ( $\mathrm{mg} / \mathrm{dL}$; dependent variable) and other variables according to either linear regression or mixed regression models inclusive of the "study effect" (Exp) using pooled data of eight experiments on stall-fed dairy sheep.

\begin{tabular}{cccccccccccc}
\hline \multirow{2}{*}{$\mathbf{X}^{2}$} & \multicolumn{3}{c}{ Intercept } & \multicolumn{3}{c}{ Slope } & \multicolumn{5}{c}{ Whole Equation $^{\mathbf{1}}$} \\
\cline { 2 - 11 } & $\mathbf{A}_{\mathbf{0}}$ & s.e. & $\boldsymbol{p}<$ & $\mathbf{B}_{\mathbf{0}}$ & s.e. & $\boldsymbol{p}<$ & $\mathbf{r m s e}$ & $\mathbf{3} \mathbf{C V}^{\mathbf{4}}$ & $\mathbf{R}^{\mathbf{2}}$ & $\boldsymbol{p}<$ \\
\hline CP (\% DM) & -25.3 & 7.5 & 0.01 & 3.9 & 0.4 & 0.001 & 7.35 & 15.97 & 0.68 & 0.001 \\
CP Exp (\% DM) & -20.7 & 8.6 & 0.05 & 3.7 & 0.5 & 0.001 & 4.89 & 10.62 & 0.82 & 0.001 \\
NDF (\% DM) & 43.1 & 11.7 & 0.001 & 0.07 & 0.3 & 0.79 & 13.11 & 28.5 & 0.001 & 0.79 \\
NDF Exp (\% DM) & 32.3 & 9.2 & 0.009 & 0.4 & 0.2 & 0.07 & 5.60 & 12.2 & 0.64 & 0.001 \\
NFC (\% DM) & 68.2 & 7.6 & 0.001 & -0.6 & 0.2 & 0.006 & 9.98 & 21.50 & 0.22 & 0.006 \\
NFC Exp (\% DM) & 69.75 & 6.9 & 0.001 & -0.6 & 0.2 & 0.001 & 4.89 & 10.52 & 0.56 & 0.001 \\
NE (Mcal/kg DM) & 145.5 & 16.7 & 0.001 & -62.4 & 10.4 & 0.001 & 9.64 & 21.00 & 0.46 & 0.001 \\
NE Exp (Mcal/kg DM) & 124.1 & 16.2 & 0.001 & -48.5 & 10.1 & 0.001 & 5.46 & 11.84 & 0.73 & 0.001 \\
CP/NE (g/Mcal) & -15.1 & 3.6 & 0.001 & 0.5 & 0.03 & 0.001 & 4.56 & 9.90 & 0.88 & 0.001 \\
CP/NE Exp (g/Mcal) & -13.7 & 4.2 & 0.014 & 0.5 & 0.03 & 0.001 & 3.30 & 7.17 & 0.93 & 0.001 \\
CPI (g/day) & 23.9 & 6.5 & 0.001 & 0.05 & 0.01 & 0.001 & 11.54 & 25.06 & 0.23 & 0.001 \\
CPI Exp (g/day) & 17.8 & 6.9 & 0.03 & 0.07 & 0.01 & 0.001 & 5.24 & 11.38 & 0.76 & 0.001 \\
\hline
\end{tabular}

${ }^{1}$ A reduced model without covariance components was implemented. Full model was not estimable.; ${ }^{2} \mathrm{X}$ is the independent regression variable, $A_{0}$ is the overall intercept, and $B_{0}$ the overall slope; $n=44$ treatment means; ${ }^{3}$ rmse $=$ root of the mean squared error; ${ }^{4} \mathrm{CV}=$ coefficient of variation. 
Both fixed and mixed regression models indicated a strong linear relation between dietary $\mathrm{CP}$ and MUC ( $R^{2}=0.82$ and 0.68 for mixed and fixed models, respectively, Table 5). The close relationship between $\mathrm{NE}_{\mathrm{L}}$ and MUC found after the analysis of pooled data from E1 and E2 (Table 4) was confirmed by the meta-analysis, with similar intercepts and slopes $\left(R^{2}=0.73\right.$ and 0.46 , for mixed and fixed models, respectively). The ratio of $\mathrm{CP} / \mathrm{NE}_{\mathrm{L}}$ was the best single predictor of MUC. The equations estimated by the two models were similar for intercept and slope, whereas $\mathrm{R}^{2}$ was slightly higher in the mixed than in the fixed model (0.93 vs. 0.88$)$. The slopes of these equations were similar to those reported after E1 and E2 regression analysis (Table 4). A positive relationship was found between NDF and MUC, but only when the mixed model was implemented. As expected, when MUC was regressed against NFC, the slopes were negative and identical between the two models $(p<0.001$, Table 5$)$. As regards the intake of nutrients, only when MUC was regressed against CPI did the relationship became significant, with a higher determination coefficient and lower root of the mean squared error (rmse) in the mixed model $\left(R^{2}=0.76, p=0.001\right.$, Table 5).

\section{Discussion}

In both experiments, the small particle size of the diets did not seem to impose physical constraints to DMI, which was probably regulated mostly by the energy demand. The overall lower DM and $\mathrm{CP}$ intake values observed in late-lactation ewes were probably due to the lower requirements of the animals with decreased milk yield, typical of this stage; particularly high MUC values were probably due to an excess of protein concentration compared with the needs of the animals.

\subsection{Results of E1 and E2}

Average group data were used in these analyses, because MUC urea is usually sampled for groups of ewes and not individually and for the need of developing relationships comparable with those developed in the meta-analysis, based on treatment means in the literature.

The non-significant relationship between MUC and dietary CP concentration (Table 4 ) was very likely due to the small variation in dietary CP considering both experiments (from $17.5 \%$ to $19.8 \%$ of $\mathrm{DM}$; Table 2). Milk urea concentration was more related to the soluble $\mathrm{N}$ fractions of the diets than to total dietary CP. In particular, the B1 protein fraction was more strongly associated with MUC than the A protein fraction, despite its lower presence in the diets. This result could be explained by (i) the wider range of variation of the fraction B1 in the diets under study and (ii) the likely variability in its utilization at the rumen level. Indeed, while fraction A is usually completely fermented in the rumen, part of fraction B1 can escape the rumen, depending on the combination of its degradation and passage rates [28], which in turn affects the partitioning of potentially degradable CP into rumen degradable (RDP) and rumen undegradable protein (RUP). Indeed, the dietary percentage of RDP and RUP influenced milk urea $\mathrm{N}$ in sheep fed almost isoenergetic diets, with higher milk urea $\mathrm{N}$ values in ewes fed $14 \%$ RDP and $4 \%$ RUP (DM basis) than in those fed $12 \%$ RDP and $4 \%$ RUP (DM basis, [25]).

The significant regression of MUC against dietary $\mathrm{NE}_{\mathrm{L}}$ found in this study on dairy sheep (Table 4) is in agreement, as a general trend, with previous studies on dairy cows [7] and goats [8]. This result suggests that enhancing the energy content of the diet increases the uptake of $\mathrm{N}$ by rumen microorganisms and reduces amino acid gluconeogenetic utilization, thus reducing the wastage of $\mathrm{N}$. In the present study, the range of dietary $\mathrm{NE}_{\mathrm{L}}$ was set to be much wider than in other previously cited experiments conducted on sheep [6,9] in order to cover the range of the energy densities frequently experienced by lactating dairy sheep (from 1.20 to $1.95 \mathrm{of} \mathrm{NE}_{\mathrm{L}}$ per $\mathrm{kg} \mathrm{DM}$, [29]). Interestingly, although MUC was highly associated with $\mathrm{NE}_{\mathrm{L}}$, it was poorly associated with dietary NFC and NDF, suggesting that the overall energy availability was more important as a determinant of MUC than the carbohydrate sources (fibrous or starchy) from which the energy was derived.

In this study, the passage rate was high for all the diets due to the small particle size of the pellets, as reported elsewhere $[16,30]$. This suggests that fermentable energy in the rumen was probably the main limiting factor for $\mathrm{N}$ utilization, as also indicated by the negative relationship between NFC 
content and MUC and the positive relationship between fiber fractions concentrations and MUC found in our study. Another reason for high levels of MUC in the sheep fed high-fiber diets could be the poor synchronization between energy and N supply at the rumen level, as shown in sheep [31].

As expected, MUC was strongly and positively related to PDIN balance (expressed as \%), in agreement with the results obtained in Saanen goats [8]. These authors reported a regression equation with a higher coefficient of determination $\left(R^{2}=0.92\right)$ than that found in our experiment $\left(R^{2}=0.54\right)$. Interestingly the slopes of the regressions for dairy sheep and goats were similar $(0.28$ and $0.34 \mathrm{mg} / \mathrm{dL}$, respectively), unlike the intercepts ( 26.9 and $22.9 \mathrm{mg} / \mathrm{dL}$, respectively). The lower value of the intercept found in the goat regression could be ascribed to their more efficient recycling of urea from blood to the rumen in goats than sheep [32]. According to this author, the greater secretion of saliva and the broader rumen surface for $\mathrm{NH}_{3}$ absorption in goats would explain the differences in MUC values among these animal species. Another possible explanation of the higher values of MUC in sheep compared with goats (and cattle) is their higher consumption of sulfur-containing amino acids for wool production. Therefore, sheep have a lower efficiency of conversion of metabolizable protein to net protein and thus higher ammonia wastage than cattle and goats, as suggested by [33] and [10].

\subsection{Results of the Meta-Analyses}

Pooling the data of E1 and E2 with those from other studies allowed to evaluate to what extent the relationships found in the present research fit a broader database (Table 5). The strict relationship ( $R^{2}$ $=0.82, p<0.001$ ) between dietary CP and MUC observed after meta-analyses confirms that the weak relationship between these variables found in E1 and E2 was strongly determined by the small range of $\mathrm{CP}$ variation between the experimental diets. Indeed, when the experiments considered a wide range of dietary CP concentration (studies 1, 6, and 7; Figure 1), the relationship between MUC and CP was tight and linear. This did not occur in the experiments with a small range of dietary CP concentration (studies 2, 3, 4, 5, and 8, Figure 1), where other experimental variables were likely more influential. Similarly, the linear relationship between $\mathrm{MUC}$ and $\mathrm{NE}_{\mathrm{L}}$ was evident only when a wide range of $\mathrm{NE}_{\mathrm{L}}$ was considered (experiments E1 and E2, which correspond to studies 2 and 3, respectively, in Figure 3). In contrast, all the studies included in the reviewed dataset were characterized by a good relationship between MUC and $\mathrm{CP} / \mathrm{NE}_{\mathrm{L}}$ ratio (Figure 2). Moreover, the residual plot distribution from the mixed model analysis, which includes the random effect of study, showed that the distribution of residual errors was closer to zero when $\mathrm{CP} / \mathrm{NE}_{\mathrm{L}}$, rather than $\mathrm{CP}$ or $\mathrm{NE}_{\mathrm{L}}$, was used as the single predictor of MUC. The adjusted values of MUC based on the model residuals and the equation obtained from the meta-regression model plotted against $\mathrm{CP} / \mathrm{NE}_{\mathrm{L}}$ values are shown in Figure 4.

This is in agreement, as a general trend, with what it was found in a study on dairy cows [4], suggesting that the ratio between dietary protein and energy content is more related to MUC than their singular concentrations or intakes.

The above considerations confirm that MUC can have a practical application for assessing the adequacy of protein nutrition in dairy ewes [10] and also point out that the 'modulation effect' of dietary energy has to be taken into account. According to [34], other dietary components, such as tannic phenols, can contribute to this modulation, particularly when ruminants are exposed to plant secondary metabolites, which is a common situation under grazing conditions. 


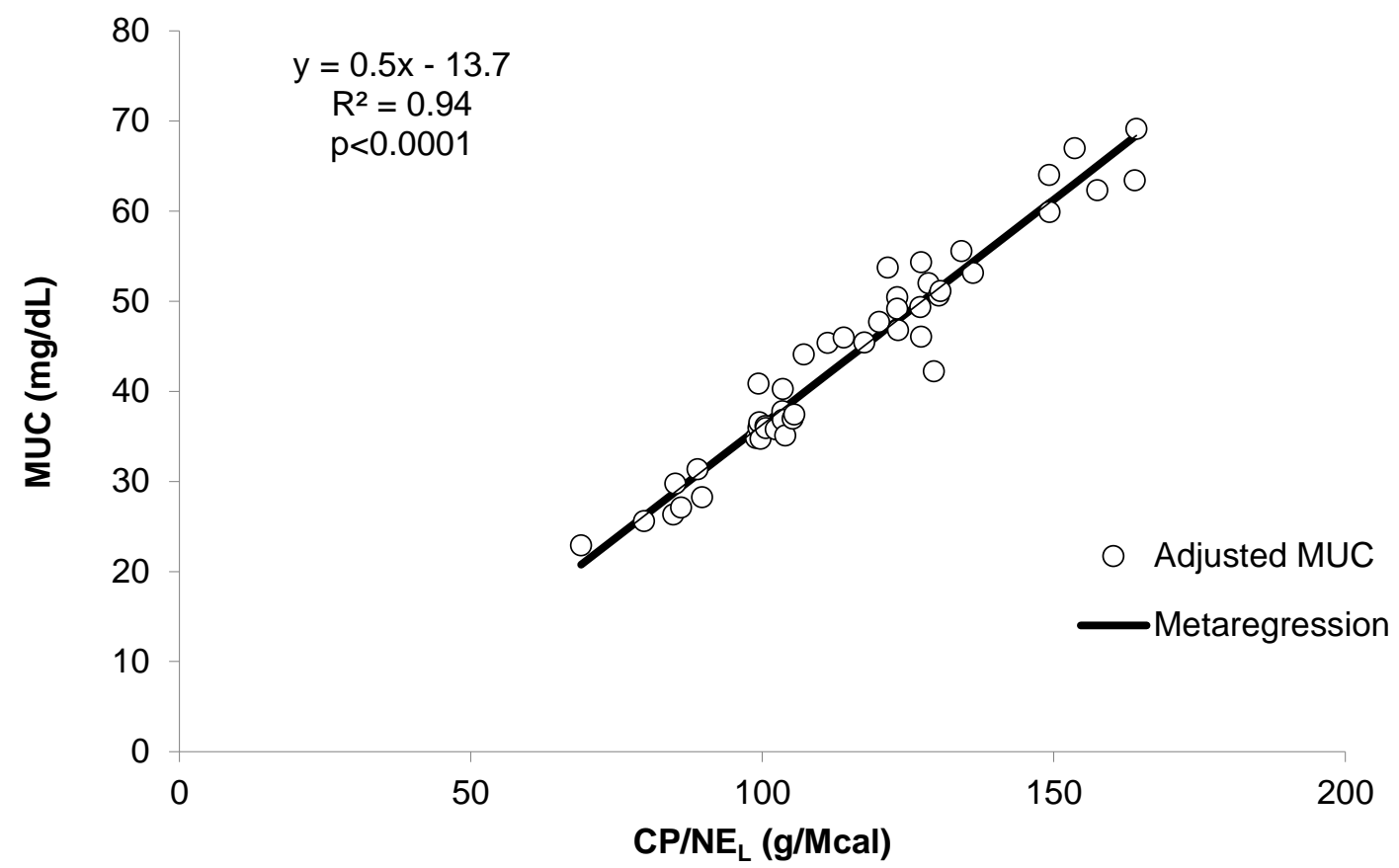

Figure 4. Relationship between milk urea concentration $(\mathrm{mg} / \mathrm{dL})$ and the ratio among crude protein and net energy for lactation $\left(\mathrm{CP} / \mathrm{NE}_{\mathrm{L}}, \mathrm{g} / \mathrm{Mcal}\right)$ as obtained from the meta-regression analysis.

\subsection{Practical Applications}

Milk urea concentration in dairy sheep farms can be easily and cost-effectively analyzed in bulk tank samples. This suggests that MUC can be used as a diagnostic tool to monitor the nutritional status of groups of lactating ewes in view of optimizing both milk [6] and reproductive performance [35], while curbing the release of $\mathrm{N}$ from excreta.

Based on the results of the meta-analysis (Table 5), MUC can be estimated according to the following equation:

$$
\operatorname{MUC}(\mathrm{mg} / 100 \mathrm{~mL})=-13.7+0.5 \mathrm{CP} / \mathrm{NE}_{\mathrm{L}}(\mathrm{g} / \mathrm{Mcal}) .
$$

This equation was used in Table 6 to predict the level of MUC corresponding to different $\mathrm{CP}$ and $\mathrm{NE}_{\mathrm{L}}$ concentrations in the diet of lactating ewes. Thus, as long either $\mathrm{CP}$ or and $\mathrm{NE}_{\mathrm{L}}$ concentration is known, the other variable can be predicted by measuring MUC.

Table 6. Milk urea concentrations (MUC) as a function of dietary energy $\left(\mathrm{NE}_{\mathrm{L}}\right)$ and protein $(\mathrm{CP})$ concentrations based on the following equation: $\mathrm{MUC}(\mathrm{mg} / 100 \mathrm{~mL})=-13.7+0.5 \mathrm{CP} / \mathrm{NE}_{\mathrm{L}}(\mathrm{g} / \mathrm{Mcal})$. The grey area (numbers in italics) is at risk of decreases in sheep fertility and impaired sheep health in the long term.

\begin{tabular}{cccccccccc}
\hline \multirow{2}{*}{ Dietary NE } & \multicolumn{1}{c}{ Dietary CP (g/kg DM) } \\
\cline { 2 - 10 } & $\mathbf{1 2 0}$ & $\mathbf{1 3 0}$ & $\mathbf{1 4 0}$ & $\mathbf{1 5 0}$ & $\mathbf{1 6 0}$ & $\mathbf{1 7 0}$ & $\mathbf{1 8 0}$ & $\mathbf{1 9 0}$ & $\mathbf{2 0 0}$ \\
\hline 1.2 & 36 & 40 & 45 & 49 & 53 & 57 & 61 & 65 & 70 \\
1.3 & 32 & 36 & 40 & 44 & 48 & 52 & 56 & 59 & 63 \\
1.4 & 30 & 33 & 36 & 40 & 43 & 47 & 51 & 54 & 58 \\
1.5 & 27 & 30 & 33 & 36 & 40 & 43 & 46 & 50 & 53 \\
1.6 & 25 & 27 & 30 & 33 & 36 & 39 & 43 & 46 & 49 \\
1.7 & 22 & 25 & 27 & 30 & 33 & 36 & 39 & 42 & 45 \\
\hline
\end{tabular}

The grey area reported in Table 6 represents a risk zone; it reports MUC values close to or higher than $56 \mathrm{mg} / 100 \mathrm{~mL}$, indicated by [35] as a threshold above which there is high probability of impairment of reproductive function in sheep with a decrease of conception rate. 
The MUC levels, reported in Table 6, are higher than the corresponding estimates based on the regression equation developed by [6] using their experimental data and data from the literature, except for diets with high $\mathrm{NE}_{\mathrm{L}}$ concentration (equal to or higher than $1.6 \mathrm{Mcal} / \mathrm{kg}$ of DM) and $\mathrm{CP}$ concentration (equal to or higher than $15 \%$ CP, DM basis), for which the values are similar between the two studies.

This discrepancy may be related to the fact that the database used by Cannas et al., 1998 [6] to develop their equations included not only milk urea data but also plasma urea data from experiments on non-lactating sheep, which had much lower dietary CP and CPI than the lactating animals. In contrast, our extended database is focused on milk urea, by itself usually higher than blood urea at equal nutritional conditions, from lactating ewes fed, in most cases, diets characterized by a positive PDI balance and high dietary $\mathrm{CP}$ and CPI. Indeed, not only the dietary $\mathrm{CP}$ but also the CPI positively affects MUC (Table 5).

In addition, [6] considered both blood and milk urea in their relationship, thus including in their analysis dietary treatments applied to dry ewes characterized by lower protein levels than those typical of lactating sheep rations. It is noteworthy that MUC levels as high as $50 \mathrm{mg} / \mathrm{dL}$ are not uncommon in sheep flocks grazing immature pasture with a high content of readily fermentable N. Therefore, the incorporation of high CP dietary treatments in the meta-analysis seems an important way to account for these excess conditions, frequently encountered in commercial dairy flocks.

If the independent and the dependent variables of the equation above are swapped around, the following equation is obtained:

$$
\mathrm{CP} / \mathrm{NE}_{\mathrm{L}}(\mathrm{g} / \mathrm{Mcal})=39.96+1.61 \mathrm{MUC}(\mathrm{mg} / 100 \mathrm{~mL}) ; \mathrm{rmse}=5.78, \mathrm{R}^{2}=0.93, p<0.001
$$

Equation (6) indicates that measurements of MUC can provide an accurate prediction of the $\mathrm{CP} / \mathrm{NE}_{\mathrm{L}}$ ratio of the diet. Thus, if either $\mathrm{CP}$ or $\mathrm{NE}_{\mathrm{L}}$ concentrations are known, MUC can be used to estimate the other unknown variable, e.g., by interpolation of data in Table 6.

\section{Conclusions}

The experiments undertaken in this study found a marked negative linear relationship between dietary energy content and milk urea level in dairy ewes in mid and late lactation. The dietary $\mathrm{NE}_{\mathrm{L}}$ content was the best singular predictor of MUC, closely followed by the $\mathrm{CP} / \mathrm{NE}_{\mathrm{L}}$ ratio. In contrast, MUC was not associated with dietary $\mathrm{CP}$ content because of the very small range of $\mathrm{CP}$ variation between the tested diets. The relevance of the dietary energy content and of the $\mathrm{CP} / \mathrm{NE}_{\mathrm{L}}$ ratio, as predictors of MUC, was confirmed after the meta-analyses of the extended database.

Further research is needed to improve the value of MUC as a nutritional index in the management of feeding in dairy sheep, especially under grazing conditions not considered in this research.

Author Contributions: Conceptualization, A.C. and G.M.; methodology, A.C., G.M., V.G., and F.B.; formal analysis, V.G., M.D., G.C.B., and G.M.; writing—original draft preparation, V.G.; writing—review and editing, A.C. and A.S.A.

Funding: This research was funded by CARGILL Animal Nutrition and SheepToShip LIFE 15 CCM/IT/000123.

Acknowledgments: The authors are grateful to Ana Helena Dias Francesconi from the University of Sassari, who revised the manuscript, and to the field and laboratory technicians of the Bonassai research station of AGRIS and of the Dipartimento di Agraria of the University of Sassari who contributed to this work.

Conflicts of Interest: The authors declare no conflicts of interest regarding this study.

\section{References}

1. Hennessy, D.W.; Nolan, J.V. Nitrogen kinetics in cattle fed a mature subtropical grass hay with and without protein meal supplementation. Aust. J. Agric. Res. 1988, 39, 1135-1150. [CrossRef]

2. Harmeyer, J.; Martens, H. Aspects of urea metabolism in ruminants with reference to the goat. J. Dairy Sci. 1980, 63, 1707-1728. [CrossRef] 
3. Zhai, S.W.; Liu, J.X.; Ma, Y. Relation between milk urea content and nitrogen excretion from lactating cows. Acta Agric. Scand. A. 2005, 55, 113-115. [CrossRef]

4. Oltner, R.; Wiktorsson, H. Urea concentrations in milk and blood as influenced by feeding varying amounts of protein and energy to dairy cows. Livest. Prod. Sci. 1983, 10, 457-467. [CrossRef]

5. Butler, W.R.; Calaman, J.J.; Beam, S.W. Plasma and Milk Urea Nitrogen in Relation to Pregnancy Rate in Lactating Dairy Cattle. J. Anim. Sci. 1996, 74, 858-865. [CrossRef]

6. Cannas, A.; Pes, A.; Mancuso, R. Effect of Dietary Energy and Protein Concentration on the Concentration of Milk Urea Nitrogen in Dairy Ewes. J. Dairy Sci. 1998, 81, 499-508. [CrossRef]

7. Broderick, G.A. Effects of Varying Dietary Protein and Energy Levels on the Production of Lactating Dairy Cows. J. Dairy Sci. 2003, 80, 1370-1381. [CrossRef]

8. Rapetti, L.; Colombini, S.; Galassi, G.; Crovetto, G.M.; Malagutti, L. Relationship between milk urea level, protein feeding and urinary nitrogen excretion in high producing dairy goats. Small Rumin. Res. 2014, 121, 96-100. [CrossRef]

9. Cannas, A.; Cabiddu, A.; Bomboi, G.; Ligios, S.; Floris, B.; Molle, G. Decreasing dietary NFC concentration during mid-lactation of dairy ewes: Does it result in higher milk production? Small Rumin. Res. 2013, 111, 41-49. [CrossRef]

10. Cannas, A. Feeding of lactating ewes. In Dairy Sheep Nutrition; Pulina, G., Ed.; CABI Publishing: Wallingford, UK, 2004; pp. 79-108.

11. St-Pierre, N.R. Invited review: Integrating quantitative findings from multiple studies using mixed model methodology. J. Dairy Sci. 2001, 84, 741-755. [CrossRef]

12. Sauvant, D.; Schmidely, P.; Daudin, J.J. Les méta-analyses des données expérimentales: Applications en nutrition animale. INRA Prod. Anim. 2005, 18, 63-73.

13. Nousiainen, J.; Shingfield, K.J.; Huhtanen, P. Evaluation of Milk Urea Nitrogen as a Diagnostic of Protein Feeding. J. Dairy Sci. 2004, 87, 386-398. [CrossRef]

14. Spek, J.W.; Dijkstra, J.; van Duinkerken, G.; Hendriks, W.H.; Bannink, A. Prediction of urinary nitrogen and urinary urea nitrogen excretion by lactating dairy cattle in northwestern Europe and North America: A meta-analysis. J. Dairy Sci. 2013, 96, 4310-4322. [CrossRef]

15. Nutrient Research Council (NRC). Nutrient Requirements of Small Ruminants: Sheep, Goats, Cervids, and New World Camelides; National Academy Press: Washington, DC, USA, 2007.

16. Boe, F. Effects of Dietary Carbohydrates on Milk Production, Feed Utilization, and Feeding Behaviour of Dairy Sheep. Ph.D. Thesis, University of Sassari, Sassari, Italy, 2006.

17. Baumont, R.; Dulphy, J.P.; Sauvant, D.; Meschy, F.; Aufrère, J.; Peyraud, J.L. Valeur alimentaire des fourragges et des matières premières: Tables et prévision. In Alimentation des Bovins, Ovins et Caprins; Éditions Quæ: Versailles, France, 2010; pp. 153-183. ISBN 978-2-7592-0874-6.

18. Hassoun, P.; Bocquier, F. Alimentation des ovins. In Alimentation des Bovins, Ovins et Caprins; Éditions Quæ: Versailles, France, 2010; pp. 123-138. ISBN 978-2-7592-0874-6.

19. Helrich, K. AOAC: Official Methods of Analysis (Volume 1), 15th ed.; Association of Official Analytical Chemists, Inc.: Arlington, VA, USA, 1990.

20. Van Soest, P.J.; Robertson, J.B.; Lewis, B.A. Methods for dietary fiber, neutral detergent fiber, and nonstarch polysaccharides in relation to animal nutrition. J. Dairy Sci. 1991, 74, 3583-3597. [CrossRef]

21. Licitra, G.; Hernandez, T.M.; Soest, P.J.V. Standardization of procedures for nitrogen fractionation of ruminant feeds. Anim. Feed Sci. Technol. 1996, 57, 347-358. [CrossRef]

22. Martillotti, F.; Antongiovanni, M.; Rizzi, L.; Santi, E.; Bittante, G. Metodi di Analisi per la Valutazione Degli Alimenti D'impiego Zootecnico; CNR/IPRA: Milan, Italy, 1987.

23. Cannas, A.; Pes, A.; Fresi, S.; Serra, F.; Pulina, G. Effects of feeding level and type of dietary protein supplement on milk urea content in ewes. In Proceedings of the Abstracts of the 48th Annual Meeting of the European Association of Animal Production, Wien, Austria, 25-28 August 1997. Poster S3.35.

24. Ubertalle, A.; Fortina, R.; Battaglini, L.M.; Mimosi, A.; Profitti, M. Effect of protein degradability on urea nitrogen in sheep milk. Scienza e Tecnica Lattiero Casearia. 1998, 49, 67-81.

25. Mikolayunas-Sandrock, C.; Armentano, L.E.; Thomas, D.L.; Berger, Y.M. Effect of protein degradability on milk production of dairy ewes. J. Dairy Sci. 2009, 92, 4507-4513. [CrossRef] 
26. Mikolayunas, C.; Thomas, D.L.; Armentano, L.E.; Berger, Y.M. Effect of rumen-undegradable protein supplementation and fresh forage composition on nitrogen utilization of dairy ewes. J. Dairy Sci. 2011, 94, 416-425. [CrossRef]

27. SAS, Version 8.1; SAS Institute Inc.: Cary, NC, USA, 2000.

28. Van Soest, P.J. The Nutritional Ecology of the Ruminant, 2nd ed.; Cornell University Press: Ithaca, NY, USA, 1994.

29. Molle, G.; Decandia, M.; Cabiddu, A.; Landau, S.Y.; Cannas, A. An update on the nutrition of dairy sheep grazing Mediterranean pastures. Small Rumin. Res. 2008, 77, 93-112. [CrossRef]

30. Cannas, A.; Boe, F.; Giovanetti, V.; Zerbini, E.; Molle, G. The rumen passage rate of forage NDF is highly associated only to the level of intake of dietary NDF. J. Dairy Sci. 2007, 90, 617.

31. Witt, M.W.; Sinclair, L.A.; Wilkinson, R.G.; Buttery, P.J. The effects of synchronizing the rate of dietary energy and nitrogen supply to the rumen on milk production and metabolism of ewes. Anim. Sci. J. 2000, 71, 187-195. [CrossRef]

32. Silanikove, N. The physiological basis of adaptation in goats to harsh environments. Small Rumin. Res. 2000, 35, 181-193. [CrossRef]

33. Bocquier, F.; Theriez, M.; Brelurut, A. Recommandations alimentaires pour le brebis en lactation. In Alimentation des Ruminants: Révision du Système et des Tables de l'INRA Bull. Tech.; Centre de Recherches Zootechniques et Veterinaires de Theix: Ceyrat, France, 1987; pp. 199-211.

34. Molle, G.; Giovanetti, V.; Cabiddu, A.; Cuccureddu, M.; Scanu, G.; Decandia, M. Milk urea as nutritional indicator in sheep grazing legume-based pastures. In Nutritional and Foraging Ecology of Sheep and Goats, Proceedings of CIHEAM/FAO/NAGREF, Zaragoza, Spain, 11-13 October 2007; Papachristou, Z.M., Parissi, H., Ben Salem, P., Morand-Fehr, P., Eds.; 2009; pp. 141-146.

35. Branca, A.; Molle, G.; Sitzia, M.; Decandia, M.; Landau, S. Short-term dietary effects on reproductive wastage after induced ovulation and artificial insemination in primiparous lactating Sarda ewes. Anim. Reprod. Sci. 2000, 58, 59-71. [CrossRef]

(C) 2019 by the authors. Licensee MDPI, Basel, Switzerland. This article is an open access article distributed under the terms and conditions of the Creative Commons Attribution (CC BY) license (http://creativecommons.org/licenses/by/4.0/). 